\title{
COTIDIANO, RACIONALIDADE E SEREIAS: o "dilema do prisioneiro" como metáfora da questão ambiental
}

\author{
Ricardo Barbosa Lima* \\ Maria das Graças Rua**
}

\begin{abstract}
Resumo: $\mathrm{O}$ artigo parte da constatação de que, entre os brasileiros, a existência de uma horizontal e disseminada consciência ambiental não se faz acompanhar de uma prática cotidiana consistente. Ou seja, mesmo diante do diagnóstico da crise ecológica global ou dos limites do crescimento do atual padrão de desenvolvimento socioeconômico, os indivíduos parecem agir no sentido de sua auto-destruição. A pergunta que então se apresenta é: O que leva indivíduos bem informados sobre como e por que agir corretamente, a não fazê-lo? Como explicar este fenômeno? Neste pequeno artigo propomos uma aproximação entre a problemática ambiental, o descompasso entre o que se professa e o que se pratica, e o instrumental teóricometodológico proposto por Elster.
\end{abstract}

Palavras-chave: ação racional; crise ambiental; Elster.

Focalizando o imaginário brasileiro, o professor Hector Ricardo Leis expressou, durante a II Jornada Internacional sobre Representações Sociais ${ }^{1}$, um ponto de vista bastante interessante. Conforme afirmou, as primeiras pesquisas de âmbito nacional ${ }^{2}$ já indicavam que o cidadão comum no Brasil seria razoavelmente bem informado sobre as questões e problemas ambientais. Inicialmente, segundo a sua observação, esses resultados deixaram muitos estudiosos bastante entusiasmados. Porém, com o passar dos anos esse entusiasmo

\footnotetext{
* Doutorando do Centro de Desenvolvimento Sustentável (CDS-UnB) e pesquisador da Universidade Federal de Goiás.

** Professora do Centro de Desenvolvimento Sustentável (CDS-UnB).

Artigo recebido em 10 jul. 2003; aprovado em 12 ago. 2003.
} 
foi se desfazendo, na medida em que se percebia que conhecimento aferido não se traduzia diretamente em ações: a densidade dos discursos e representações se esmaecia nas práticas individuais e coletivas. Ou seja, haveria entre os brasileiros uma razoável e horizontal e disseminada consciência ambiental (que por várias vezes foi traduzida em demandas por melhores condições de vida em harmonia com a natureza), mas uma prática, no mínimo, a meio caminho do tão propalado "agir ecologicamente correto".

Essa constatação chama a atenção na medida em que, por um lado, tem se destacado, nas últimas décadas, a capacidade do ideário ambientalista $^{3}$ de perpassar diferentes segmentos sociais. Por outro, essa capacidade de fertilizar e informar os grupos sociais parece não se traduzir em práticas sociais condizentes; pelo menos, não com o mesmo rigor e freqüência com que a ladainha do "ecologicamente correto" é apregoada. Mas ainda, os indivíduos que professam esses ideais (que se dizem deles sabedores e/ou defensores), por vezes, parecem, eles mesmos, não se orientarem por esses preceitos. E se pensarmos nos custos coletivos desse descompasso entre o que se professa e o que se faz, os resultados parecem ser ainda mais destoantes.

O que leva um indivíduo bem informado sobre como e por que agir corretamente, a se comportar diversamente disso? Ou seja, tendo em vista resultados possíveis, em uma perspectiva macro, acentuar a degradação ambiental do planeta e, em uma dimensão micro, contribuir para prejudicar a sua própria qualidade de vida? Aqui está, ao nosso entender, o grande dilema revelado pela crítica ambiental ao modelo atual de desenvolvimento. Mesmo diante do diagnóstico da crise ecológica global ou dos limites do crescimento do atual padrão de desenvolvimento socioeconômico, os indivíduos parecem agir no sentido de sua auto-destruição. Como explicar este fenômeno?

Na obra Peças e Engrenagens das Ciências Sociais, Jon Elster apresenta o que denomina "mecanismos causais que servem de unidades básicas das ciências sociais" (Elster, 1994, p. 13). Argelina Figueiredo descreve assim o esforço analítico proposto pelo autor: 
Em Peças e Engrenagens, Elster enfatiza a explicação por mecanismos. $\mathrm{O}$ conceito de mecanismo utilizado, deve-se observar, não guarda qualquer proximidade a uma visão mecanicista geral do funcionamento da sociedade. Ao contrário. Explicar é explicitar os mecanismos causais, abrir a caixa preta, mostrar as peças e as engrenagens, a maquinaria cuja operação produz o fenômeno a ser explicado. Explicar por mecanismos significa mostrar, em toda a sua riqueza e complexidade, a cadeia causal que faz a mediação entre explanans e explanandum [...] uma categoria intermediária entre teoria e descrição. (Figueiredo, 1994, p. 8)

Neste pequeno artigo, pretendemos uma aproximação entre a problemática ambiental, o descompasso entre o que se professa e o que se pratica, e o instrumental teórico-metodológico proposto por Elster. Para tanto, primeiramente apresentaremos um pouco da caixa de peças e engrenagens propiciada pelo individualismo metodológico de Jon Elster. Em seguida procuraremos problematizar, a partir de dois exemplos de escolha racional apresentados por Elster (1994,1989) - o Dilema do Prisioneiro e a Racionalidade Imperfeita: Ulisses e as Sereias - as possibilidades da ação racional para superar os desafios postos aos indivíduos pela anunciada crise ambiental. ${ }^{4}$

\section{A explicação intencional-causal, segundo Jon Elster}

Para Jon Elster, existem basicamente três maneiras de explicar cientificamente os fatos e os eventos: ${ }^{5}$ a explicação causal, a explicação funcional e a explicação intencional. Nesses limites, afirma que todas as ciências utilizam a explicação causal. As ciências físicas só utilizam a explicação causal. Na biologia não há lugar para a explicação intencional e nas ciências sociais não há lugar para a funcional.

No que concerne ao foco do presente artigo - o estudo da conduta humana diante dos problemas ambientais - as explicações biológicas disputam, ainda hoje, a prerrogativa da explicação tanto da origem do fenômeno quanto das possibilidades de seu enfrentamento. No livro O Futuro da Vida, Edward Wilson, um dos fundadores da sociobiologia, ${ }^{6}$ sugere que a capacidade das Ciências 
Sociais de prever (explicar) os desastres políticos e econômicos está intimamente ligada ao desvelamento de sua origem biológica:

Dentro de algumas décadas, acreditam muitos neurocientistas, conheceremos as bases biológicas da mente e do comportamento. Isto, por sua vez, levará a grandes progressos nas ciências sociais e a uma melhor capacidade de prever e evitar desastres políticos. (Wilson apud Leite, 2002, p. 28)

A própria possibilidade de sobreviver às ameaças da degradação da biosfera - ou seja, de conservar a biodiversidade seria função da capacidade de adaptação evolutiva (darwiniana) programada dos genes do comportamento social. Pois é por meio dela que surgem as emoções que fundam, até mesmo, a nossa consciência moral:

Outro valor moral extremamente importante é a responsabilidade pelas outras formas de vida, que parece surgir de emoções programadas nos próprios genes do comportamento social humano [...]. Um sentido de unidade genética, de parentesco, de vida em comum, que nos une às outras espécies que habitam a Terra. (Wilson apud Leite, 2002, p. 28) (grifo nosso)

Elster (1989, p. 9-10), porém, mesmo fazendo uma ressalva de que "no toda conducta animal es funcional, y no toda conducta humana es racional o intencional", defende que

[...] as Ciências Sociais devem oferecer explicações intencionaiscausais, ou seja, a explicação intencional das ações individuais juntamente com a explicação causal da interação entre os indivíduos. A explicação obedeceria, assim, a dois estágios: primeiro é necessário explicar porque macroestados no tempo $t$ influenciaram o comportamento dos indivíduos motivados por certos objetivos; em seguida, explicar como essas ações individuais contribuem para novos macroestados no tempo $t+1$. (Figueiredo, 1994, p. 7-8)

Ainda que o autor reconheça que "a análise funcionalista na sociologia tem uma longa história" (Elster, 1989b, p. 165), a explicação funcional-causal é por ele descartada na medida em que supõe que os eventos possam ser explicados não pelas suas causas, mas por suas consequiências esperadas, reivindicando um processo sem sujeito, de forma a postular um propósito sem seu autor. ${ }^{7}$ 
Entretanto, Elster não apela estritamente à intencionalidade como o mecanismo explicativo da conduta humana. Não há nesse autor nem mesmo a reivindicação de um exclusivismo da explicação social à maneira de Durkheim. O que não se deve fazer é ceder à tentação e querer ver nessas brechas deixadas pela razão instrumental uma explicação funcional presa, em última instância, a uma função mais ou menos latente do organismo como sugere o texto acima: uma função programada do gene.

José C. Vázquez, que cuidou da edição espanhola de Ulisses e as Sereias (1989), sintetiza de maneira primorosa essa peculiar e engenhosa maneira de postular uma abordagem interdisciplinar fundada no rigor teórico do individualismo metodológico, da qual Jon Elster é um dos principais precursores:

Situado en el cruce de disciplinas como la biología, la sociología, la literatura y las matemáticas, el propósito de este libro es hacer una descripción y un análisis interpretativo de los comportamientos racional e irracional. Dejando de lado la analogía funcionalista, que pretendía explicar la conducta del hombre refiriéndola al sustrato puramente biológico, la actitud racional - entendida como una capacidad para relacionarse con el futuro - se estabiliza como definidora de lo humano, no obstante los grados, imperfecciones y problemas que presenta en su ejecución concreta. (Vázquez, 1989).

Sendo rigoroso com a premissa de que é a intencionalidade que sustenta, via de regra, a explicação para as ações humanas - que funda a capacidade humana de se relacionar com o futuro ${ }^{8}$ - não há saída lógica a não ser aceitar o desafio de revelar os mecanismos causais (racionais ou irracionais) da conduta individual. A unidade de análise é, como não poderia deixar de ser, o indivíduo. A intencionalidade não está pré-programada nos genes do comportamento humano como quer Wilson (2002), mas deve ser interpretada diante da estrutura de oportunidades e desejos à disposição do indivíduo isolado (subintencional) ou em interação com outros (supraintencional). Para Elster, é na intercessão dessas condutas - a ação humana individual e a interação dos indivíduos - e na interpretação dos seus vários arranjos, que o individualismo metodológico se apresenta como instrumental teórico válido. 
Segundo Elster (1990), para a explicação da conduta humana concorrem a racionalidade e as normas sociais. No primeiro caso, na ação individual, o homem se apresenta como o homo economicus de Adam Smith, orientando suas ações pela lógica maximizadora dos seus interesses; no segundo, na interação social, o indivíduo se apresenta como o homo sociologicus de Émile Durkheim, subordinado ao jogo de forças sociais que lhe são externas e anteriores.

A ação racional refere-se a resultados. A racionalidade diz que se você deseja atingir $Y$, deve fazer $X$. Eu defino, ao contrário, as normas sociais pelo seu caráter de não serem orientadas por resultados. As normas sociais mais simples são do tipo "faça $X$ ou não faça $X$ ". Normas mais complexas dizem que se você deseja fazer $Y$, então deve fazer $X$, ou que, se outros fizerem $Y$, então deve fazer $X$. Normas mais complexas ainda poderiam mandar fazer $X$, se for bom que todos façam $X$. A racionalidade é essencialmente condicional e orientada para o futuro; ao contrário, as normas sociais tendem a ser incondicionais, ou quando condicionais, não são orientadas para o futuro (Elster, 1990, p. 56).

$\mathrm{O}$ autor sustenta que tanto as normas quanto o interesse próprio compõem explicações para as condutas individuais, mas esse equilíbrio pode ser rompido a qualquer momento. Isto é, a escolha da norma pode, em várias situações, "ser, em certa medida, explicada pelo interesse" mas, em outras, pode não acontecer "que o interesse forneça a explicação completa da adesão às normas" (1990, p. 68). Para esse autor, deve haver alguma outra explicação - " $X$ " - para a existência das normas que não a sua afinidade com o interesse racional. O diagrama abaixo ${ }^{9}$ procura resumir essas possibilidades:

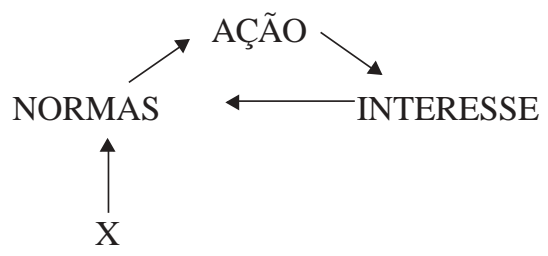

Mas essa ausência não autoriza o abandono da explicação intencional-causal. Esse é claramente o desafio imposto às Ciências 
Sociais e que, em Ulisses e as Sereias, Elster denomina estudos sobre a racionalidade e irracionalidade da conduta humana. Trata-se do esforço analítico pelo qual se procurará revelar as peças e engrenagens da causalidade subintencional e supraintencional que conformam a conduta humana, em que "la primera se refiere a los procesos causales que ocurren dentro do individuo, formando o pervirtiendo sus intenciones. [...] El último se refiere a la interacción causal entre individuos" (Elster, 1989, p. 9).

Quando postula que os indivíduos também interagem intencionalmente, de forma supraintencional, Elster (1989b) traz à tona a necessidade de se conceber os indivíduos como racionalmente estratégicos, no sentido de que a escolha racional se dá por meio da interdependência das decisões. Daí a importância da Teoria dos Jogos: ${ }^{10}$

A necessidade da teoria dos jogos surge à medida que os atores individuais cessam de ver os outros como obstáculos dados para suas ações e começam a considerá-los como seres intencionais. $\mathrm{Na}$ racionalidade paramétrica, cada um se considera uma variável e todos os outros são constantes, ao passo que na racionalidade estratégica todos vêem a todos os demais como variáveis. A essência do pensamento estratégico é que ninguém pode se considerar privilegiado em comparação aos outros: cada qual deve decidir pressupondo que os outros são tão racionais quanto ele próprio. (Elster, 1989b, p. 182)

Informação, ponto de equilíbrio e solução são os elementos essenciais das situações de jogo. Ainda que diversas modalidades desses sejam possíveis ${ }^{11}$ para os objetivos do presente texto - o dilema ambiental - basta um exemplo simples de jogo entre duas pessoas ou, no limite, com o seu desdobramento em jogos entre "eu" e o "resto" (uma redução de jogos complexos de $n$ pessoas): o dilema do prisioneiro.

Segundo Elster (1994), esse dilema exprime uma situação hipotética na qual dois indivíduos acusados de serem cúmplices em um crime são presos em celas separadas e mantidos incomunicáveis. A informação de que cada um dos prisioneiros dispõe é a seguinte: 1) cada um será posto em liberdade se denunciar o outro e este não o denunciar; 2) se denunciarem um ao outro, ambos receberão três anos 
de prisão; 3) se um não denunciar o outro, mas o seu parceiro o denunciar, será condenado a cinco anos de prisão; e 4) se nenhum denunciar o outro, a polícia tem provas suficientes para mandar cada um à prisão por um ano.

O conceito de ponto de equilíbrio é o conjunto "de estratégias em que a estratégia escolhida por cada ator é ótima ${ }^{12}$ vis-à-vis as dos outros". E o conceito de solução, definido em relação ao de ponto de equilíbrio, "é o conjunto de estratégias para o qual convergem tacitamente os atores racionais com informação perfeita" (Elster, 1989b, p. 184). Ao buscar explicar a racionalidade da ação de cada ator, dentro do leque de oportunidades e desejos que podem conformar as possibilidades lógicas de cooperação e de conflito entre os indivíduos, teremos que:

[...] é na verdade um jogo bastante trivial. A solução do jogo é o egoísmo universal. A racionalidade individual conduz ao desastre coletivo. A cooperação universal não é individualmente estável nem acessível: todos darão o primeiro passo para dela se afastar e ninguém dará o primeiro passo para dela se aproximar. (Elster, 1989b, p. 188).

No que se refere às questões ambientais, essa densidade analítica é muito bem-vinda. Principalmente diante do que chamamos, aqui, de dilema ambiental: a situação na qual, ao seu reconhecido atrativo e capacidade de mobilizar a adesão global, multifacetada e multissetorial, se contrapõe, em muitas ocasiões, a baixa efetividade da participação dos atores sociais na resolução do problema. Ou, em termos do dilema do prisioneiro, o reconhecimento da plena capacidade de fazer escolhas racionais e agir consistentemente com as mesmas não basta para evitar comportamentos cujas previsíveis conseqüências, individual e coletivamente, mostram-se desastrosas.

\section{O cálculo racional e o dilema ambiental}

De fato, se aproximarmos as situações e condições de jogo colocadas pelo dilema do prisioneiro ao que estamos chamando de "dilema ambiental", em linhas gerais, teremos o quadro da crise ecológica global apontada por diversos pesquisadores. 
Vários são os diagnósticos que apontam que a vida das gerações futuras está ameaçada pelo atual modelo de desenvolvimento. Por esse ângulo o dilema do prisioneiro parece se radicalizar, pois o que está em jogo deixa de ser somente um gradiente entre liberdade ou prisão, para expressar a possibilidade de sobrevida ou extinção. Segundo Wilson:

Se as tendências atuais se mantiverem, o resultado será o empobrecimento irreversível das espécies. No ritmo em que estamos indo hoje, perderemos metade das espécies animais e vegetais da Terra até o final do século. [..]. As estimativas mais conservadoras prevêem que a população humana chegue ao pico de 8 bilhões ou 10 bilhões de pessoas até o final do século, e isso será praticamente o limite máximo que o planeta poderá suportar a não ser que surja alguma maneira radicalmente nova de produzir alimentos ou gerar energia. As pressões sobre os recursos remanescentes - recifes de corais, florestas tropicais e tundra ártica - podem tornar-se totalmente devastadoras (Wilson, 2002, p. 26-27).

O quadro sugerido acima é bastante recorrente na história das pesquisas que têm como desafio equacionar as variáveis: meio ambiente e crescimento econômico. Os Informes ao Clube de Roma e os Relatórios do Programa das Nações Unidas para o Meio Ambiente, as pesquisas da Organização para a Cooperação e Desenvolvimento, entre outras instâncias de debate internacional do tema, produziram um sem número de alertas sobre a crise ecológica e os limites do desenvolvimento.

Na década de sessenta algumas análises sugeriam, como ocorre no dilema do prisioneiro, que as ações humanas se orientavam por uma racionalidade que conduziria ao desastre coletivo. Para o biólogo Paul Ehrlich, os indivíduos, mesmo sabendo das conseqüências da pressão demográfica sobre o meio, não conseguiriam controlar o crescimento populacional: "nenhuma mudança de comportamento ou tecnologia pode nos salvar, a não ser que possamos realizar um controle das dimensões da população humana" (Ehrlich apud McCormick, 1992, p. 83). Já Barry Commoner, acreditava que, antes mesmo de qualquer pressão demográfica, o atual padrão tecnológico, devido ao seu potencial destrutivo e poluidor (uma "tecnologia defeituosa"), 
levaria ao aniquilamento das possibilidades de vida na Terra (Commoner apud McCormick, 1992, p. 82-83)

Segundo Garret Hardin, "a inevitabilidade da destruição global predeterminava as escolhas que a humanidade deveria fazer para assegurar sua sobrevivência" (McCormick, 1992, p. 83). Utilizando a parábola da "tragédia das áreas comuns", descreve o homem como prisioneiro dos limites de sua própria ação racional. Para esse autor não é só a capacidade de carga ou uma superpopulação que está em questão. Hardin acrescenta a estas mais duas, a poluição e a geração de resíduos nocivos, como sendo incontornáveis:

[...]. cada homem está aprisionado num sistema que o impele a aumentar seu rebanho ilimitadamente - num mundo que é limitado. A ruína é o destino para o qual todos os homens caminham, cada um em defesa de seus próprios interesses [...]. O homem racional descobre que sua parte no custo dos resíduos que descarrega nas áreas comuns é menor que o custo de purificar os resíduos antes de liberá-los. Uma vez que isso é verdade para todos, enquanto nos comportarmos somente como empreendedores livres, racionais e independentes, estaremos aprisionados num sistema que 'emporcalha nosso próprio ninho' (Hardin apud McCormick, 1992, p. 85).

As possibilidades de cooperação também foram desenhadas, por outros pesquisadores, como saídas para o dilema ambiental. A Conferência das Nações Unidas sobre Meio Ambiente Humano (Estocolmo-72) e a Conferência das Nações Unidas para o Meio Ambiente e Desenvolvimento (Rio-92), são claros exemplos que postulam a cooperação para a solução do dilema ambiental.

Nessa nova situação, o que parece estar em jogo, diante do mal iminente e inevitável, seria o surgimento de áreas de solidariedade, pois indivíduos, grupos e organizações, como já apontava Elster (1990), não se movem apenas por seus interesses imediatos, por uma escolha racional baseada no cálculo das vantagens comparativas e do custo da participação. E, assim sendo, seria possível que se formassem áreas de solidariedade, pois:

Como sugere Pizzorno, o interesse de um ator significa 'a ação pela qual ele se distingue de outros atores, visando a melhorar sua posição 
relativa no confronto com estes (...) Para que tal ação seja possível é necessário que seus resultados sejam mensuráveis - isto é, passíveis de serem avaliados em termos de melhor ou pior, de mais ou menos e que o critério de mensuração seja comum ao ator e àqueles com respeito aos quais o ator pretende melhorar sua posição. (...) Um sistema de interesses comporta, portanto, um sistema de avaliações comuns que servem a um conjunto de atores ...' - ou seja, ele requer um sistema de solidariedade subjacente, ainda que os objetivos que em tal sistema se compartilham correspondam apenas às condições que permitem aos atores empenhar-se no jogo de vantagens comparativas. (Reis, 1984, p. 130)

Reconhecer, como faz Reis (1984), tomando emprestado as idéias do pensador italiano Alessandro Pizzorno, o papel da solidariedade na lógica da ação coletiva, não invalida as ponderações anteriores, mas impõe uma maior complexidade à sua análise, principalmente em relação às possíveis inferências causais supraintencionais dos eventos. Isso indica a necessidade de um controle, de uma coerção imposta de fora, já que, o indivíduo, per si, parece não cooperar voluntariamente. Na formulação proposta por Elster (1994), esse controle deve ser exercido pelas instituições sociais:

As instituições evitam que a sociedade se desmantele [...] nos protegem contra as conseqüências destrutivas da paixão e do auto-interesse, mas por outro lado, as próprias instituições correm o risco de ser minadas pelo auto-interesse, a 'ferrugem das sociedades', como chamou Tocqueville. (Elster, 1994, p. 174).

Mas diante dos problemas ecológicos globais, tal como no dilema do prisioneiro, essa instituição teria de ser capaz de forçar ou de estimular os atores para que optassem pela cooperação universal. Esta pode ser uma solução possível, já que há situações em que os indivíduos orientam o seu comportamento por normas visando reduzir a incerteza sobre as estratégias que cada um irá adotar. ${ }^{13}$ Quando as normas operam em benefício de todos, a tendência é de que cada um acredite que os demais irão observá-las e então torna-se racional "pagar na mesma moeda". Entretanto, como normas significam restrições, há enormes vantagens para qualquer indivíduo isolado que prefira violá-las, especialmente quando os demais as estão acatando. 
Este é justamente o foco do impasse presente na aplicação do Protocolo de Kyoto: por um lado, não há como agir contra as conseqüências destrutivas do auto-interesse, forçando todos a cooperar; por outro, para alguns, há grandes vantagens em não cooperar exatamente porque os demais assumem comportamentos cooperativos. Esta é uma situação fortemente provável nos contextos onde as consequências da não cooperação forem tão desastrosas para todos que cada um racionalmente tenha incentivo a cooperar se outros não o fizerem. ${ }^{14}$ A 'ferrugem das sociedades' parece ter impregnado a discussão sobre o aquecimento global. Apegando-se à estratégia de "dar um passo para trás para depois caminhar dois para frente", a sua efetivação é reiteradamente protelada: nenhum ator realmente importante ${ }^{15}$ dá o primeiro passo em direção à cooperação efetiva e todos dão um passo para dela se afastar. Esta é, tipicamente, a lógica do free-riding: cada um se comporta egoisticamente ao mesmo tempo que - e exatamente porque - se beneficia do comportamento cooperativo dos demais.

\section{Racionalidade, cotidiano, automóveis e sereias}

Esse cenário das relações internacionais parece se reproduzir no cotidiano dos indivíduos. Vários são os exemplos de descompasso entre o que pensam (ou sabem) os indivíduos sobre os problemas ambientais e suas práticas cotidianas. Trazemos aqui uma situação real ${ }^{16}$ muito próxima daquilo que os adeptos da teoria dos jogos constroem para simular condições perfeitas de desejos e oportunidades.

O campus da Universidade de Brasília comporta, além dos prédios acadêmicos e administrativos, aqueles reservados à moradia de docentes e funcionários, numa área conhecida como "Colina". A distância entre o local de moradia e o local de trabalho desses profissionais - digamos, da Colina ao Instituto Central de Ciências que concentra a maioria dos cursos - não é superior a 1500 metros ou correspondente a, no máximo, dez minutos de caminhada. Mesmo sabendo que seria ecologicamente correto, além de saudável, abrir 
mão do transporte individual mecanizado e seguir a pé - contribuindo assim para reduzir a emissão de gases estufa -, raramente algum professor ou funcionário o faz.

Levando-se em conta o ganho em agilidade e maximização do tempo proporcionado pela opção do uso do carro próprio, postulados de pronto por qualquer condutor, ${ }^{17}$ poderíamos, em contrapartida, supor que quem defende a maximização de ganhos (de tempo e agilidade), o faça também em vista da otimização dos custos..$^{18}$ Mas, por exemplo, no caso de professores e funcionários que moram em um mesmo prédio, que trabalham no mesmo Departamento e que saem de casa à mesma hora, não é comum vê-los partilharem o mesmo carro, reduzindo seus custos (e riscos) com transporte, ao mesmo tempo em que maximizam seu tempo ganhando agilidade.

Nenhuma sugestão dos órgãos superiores daquela casa de ciência para orientar ou estimular essa prática ou outras correlatas parece surtir efeito, visto que, do ponto de vista da racionalidade institucional, no mínimo, o tradicional congestionamento nos horários de rush e a falta de vagas nos estacionamentos seriam mitigados. Além disso, em muitas ocasiões, devido à falta de vagas nos estacionamentos próximos ao local de trabalho, o professor ou funcionário-condutor opta por estacionar em pontos quase tão distantes do local de trabalho quanto o próprio local de moradia. De forma que a pequena diferença em metros e/ou em tempo de deslocamento não sustentaria os argumentos pró-transporte individual.

Mesmo que esse hipotético professor ou funcionário não seja um ambientalista militante, com razoável grau de certeza é possível afirmar que ele detém um conjunto suficiente de informações para antever que sua ação o alça, se não a protagonista, à coadjuvante da degradação ambiental. ${ }^{19}$

Vale observar que nesse exemplo o que parece estar em jogo não é só a capacidade das normas sociais para levar ao agir ecologicamente correto. A escolha racional, não só da perspectiva ecológica, mas individualmente vantajosa (saudável, econômica e segura) de deslocar-se a pé ou em conjunto com outros professores é relegada cotidianamente. E se ainda levarmos em conta emoções ou 
sentimentos ligados à luxúria e à ostentação de um bem de consumo tão cobiçado como um automóvel, não seria nenhum empecilho, ao professor exibicionista, oferecer ostensivamente uma carona a um colega seu, um dos seus pares. Mas, contrariando a racionalidade individual, a tentação exibicionista, o credo ambientalista, as regras de segurança e os cuidados com a saúde, permanece o descompasso.

Nem mesmo o conceito marxista de alienação parece se aplicar. Poder-se-ia postular, em última instância, uma alienação para si, mas nunca a alienação em si. $\mathrm{O}$ indivíduo, mesmo sendo crítico à sua própria ação, não consegue colocar em marcha o seu projeto. ${ }^{20} \mathrm{E}$ não há nenhum motivo racional para não fazê-lo: nenhuma oportunidade lhe falta; o desejo de ser ecologicamente correto não é dissimulado; a instituição que o regula não é avessa aos resultados pretendidos; o auto-interesse não o proíbe. Aqui, Durkheim e Adam Smith, mesmo de mãos dadas, não explicam o mecanismo que está atuando.

Elster (1994, p. 47) ao enfrentar esse tipo de situação em que as "pessoas podem não se ajustar às suas predições", sustenta que a racionalidade pode falhar. Um mecanismo que pode estar agindo é o da "fraqueza da vontade". Mesmo diante da sua afirmada vontade de agir de modo ecologicamente correto, e tendo oportunidade e estímulo para fazê-lo, os professores e funcionários não agem nesse sentido.

Para discutir essas situações, Elster busca amparo na famosa passagem de Ulisses e a Sereias, em A Odisséia de Homero: ${ }^{21}$

Ulisses no era por completo racional, pues un ser racional no habría tenido que apelar a este recurso; tampoco era, sencillamente, el pasivo e irracional vehículo de sus cambiantes caprichos y deseos, pues era capaz de alcanzar por medios indirectos el mismo fin que una persona racional habría podido alcanzar de manera directa. Su situación - ser débil, y saberlo - señala la necesidad de una teoría de la racionalidad imperfecta que casi ha sido olvidada por filósofos y científicos sociales. [...] La tesis general que estamos defendiendo es que atarse a sí mismo es un modo privilegiado de resolver el problema de la flaqueza de voluntad; la principal técnica para lograr la racionalidad por medios indirectos. (Elster, 1989, p. 66-67). 
Portanto, para Elster (1989) a saída é atar-se a si mesmo: reconhecer a imperfeição da razão e encontrar formas para lidar com ela. Na situação empírica aqui exemplificada, porém, a racionalidade, mesmo imperfeita, volta a falhar. Ulisses, mesmo sabendo ser débil, não conseguiu "atarse a sí mismo". Nem mesmo a Universidade, detentora da ciência e guardiã das prerrogativas do agir racionalinstrumental, como instituição, não coagiu ou estimulou que o Ulissesprofessor ou funcionário ordenasse a seus sócios que o prendessem à proa, impedindo-o de navegar rumo à sua destruição.

\section{Conclusão: a fé na razão como limite à ação racional}

O que, então, estaria atuando? Qual a engrenagem que pôs em movimento de auto-destruição o indivíduo que sabe que deve evitála e como fazê-lo? A solução do dilema ambiental parece passar pelo enfrentamento da discussão dos limites da racionalidade. Tanto lá quanto cá - em âmbito subintencional e supraintencial - os atores sociais reivindicam como justificativa ou justificação de suas ações - aparentemente injustificáveis - uma crença irracional na razão: "mais cedo ou mais tarde todos esses problemas ambientais serão dominados (pela razão) através da ciência e da tecnologia". Assim se apresenta a peça que faltava nessa engrenagem: a crença irracional na razão. Ao enfrentar as Ninfas contemporâneas (a ciência e a técnica) diante do perigo do desastre ambiental, Ulisses parece ter-se atado com muita força ao mastro. A fé na ciência e no aperfeiçoamento tecnológico - um mundo organizado e explicado pela ciência e dominável pela técnica - parece estar na origem da noção de progresso e da possibilidade de um desenvolvimento ilimitado.

Weber (1982), ao buscar caracterizar a centralidade e o papel da ciência e da técnica na constituição da sociedade moderna aponta claramente a cristalização dessa crença:

A crescente intelectualização e racionalização não indicam, portanto, um conhecimento maior e geral das condições sob as quais vivemos. Significa mais alguma coisa, ou seja, o conhecimento ou crença em que, se quiséssemos, poderíamos ter esse conhecimento a qualquer 
momento. Significa principalmente, portanto, que não há forças misteriosas e incalculáveis, mas que podemos, em princípio, dominar todas as coisas pelo cálculo. (Weber, 1982, p. 37).

Aproximando-se do dilema do prisioneiro como uma metáfora da questão ambiental a pergunta correta seria: a quem caberá viver nessa prisão?22 Max Weber, em A Ética Protestante e o Espírito do Capitalismo, mais uma vez, antecipa algumas alternativas de respostas:

Ninguém sabe ainda a quem caberá no futuro viver nessa prisão, ou se, no fim desse tremendo desenvolvimento, não surgirão profetas inteiramente novos, ou um vigoroso renascimento de velhos pensamentos e idéias, ou ainda, se nenhuma dessas duas - a eventualidade de petrificação mecanizada caracterizada por esta convulsiva espécie de autojustificação. Nesse caso, "os últimos homens" desse desenvolvimento cultural poderiam ser designados como "especialistas sem espírito, sensualistas sem coração, nulidades que imaginam ter atingido um nível de civilização antes nunca alcançado" (Weber, 1989, p. 131).

O próprio Elster, segundo Argelina Figueiredo, na sua obra Salomonic Judgments: studies in the limitations of rationality indica que esse mecanismo pode estar presente: "a crença na onipotência da razão nada mais é do que uma forma de irracionalidade. A própria racionalidade requer que reconheçamos seus limites" (Figueiredo, 1994, p. 8-9).

Vencer a força dessas novas sereias, revelando ao mundo o seu segredo, parece solicitar que o ambientalista ou o homem contemporâneo percorra uma nova Odisséia na construção de seu futuro. A diferença é que já não pode contar com a ajuda dos deuses. Circe, a feiticeira filha do Sol, já não pode nos ajudar a vencer nossas fraquezas. A vitória de Ulisses sobre as Sereias desencantou o mundo, eliminando suas explicações mágicas. ${ }^{23} \mathrm{O}$ homem contemporâneo está só diante de sua debilidade. A "astúcia da razão", sua principal arma, revela-se cristalizada como uma crença arrogante, como um sedutor canto das sereias. Desatar-se delas sem atar-se a si mesmo: ${ }^{24}$ aí está o novo desafio da escolha racional. 


\section{Notas}

1 Reproduzimos aqui, em linhas gerais, a argumentação apresentada por esse pesquisador ao Grupo Temático de Discussão 08 (Representações Sociais e Meio Ambiente), em 21 de setembro de 2001, na cidade de Florianópolis (SC).

2 São várias as pesquisas que procuraram construir um quadro de referências do que pensa o brasileiro sobre meio ambiente; entre elas destacamos duas que consideramos úteis para introduzir o pesquisador ao debate:. Crespo (1997) e DaMatta (1993).

3 Para os fins deste trabalho, consideramos ideário ambientalista como toda e qualquer idéia ou plano herdeiro do pensamento liberal social, que busca elaborar a equação degradação ambiental versus desenvolvimento humano. E que, para tanto, postule equilibrar desenvolvimento econômico-social, respeito à diversidade cultural dos povos e à diversidade biológica das outras formas de vida com os limites das possibilidades de seus usos e explorações e assegurar a sobrevida com qualidade às gerações futuras. Já pensamento liberal social é aqui entendido, em linhas gerais, como aquele que oriente fortemente o seu ideário social segundo dois princípios: a defesa da liberdade individual e a preocupação em regular socialmente a esfera das funções econômicas (Ver Bellamy, 1994).

4 Nos limites deste texto, a crise ambiental será tomada aqui como um dado, isto é, não será objeto de discussão. Para tanto, ver, entre outros, Bursztyn (1984;1995); Bartholo (1984); Herrera (1984); Goldblat (1998); Linskog (1996).

5 Elster diferencia eventos de fatos: “[...] Um fato é um instantâneo temporal de uma torrente de eventos, ou uma pilha de tais instantâneos. Nas ciências sociais, os eventos elementares são ações humanas individuais, incluindo atos mentais tais como formação de crenças" (Elster 1994, p. 17).

6 Para aprofundar o debate sobre a utilização do funcionalismo sistêmico para a explicação da conduta humana (coletiva ou individual) em relação ao meio ambiente, ver a critica de Leff (2001). Esse autor enumera uma série de efeitos ideológicos, entre eles, refere-se a outra obra de Edward Wilson (Sociobioly: the new synthesis), afirmando que "estas teorias sociobiológicas desconhecem a especificidade das relações sociais de produção, das regras de organização cultural e das formas de poder político e ideológico nas quais se inscrevem as mudanças sociais e as formas de uso dos recursos produtivos" (Leff, 2001, p. 63). 
7 De acordo com Elster (1989), existe nas Ciências Sociais uma tradição de análise que se baseia na concepção de uma teleologia objetiva, ou seja, os acontecimentos são explicados por uma finalidade que os guia, mesmo que não existam evidências de um sujeito intencional ao qual se atribui esta finalidade.

8 Capacidade ao mesmo tempo denunciada e postulada pela crítica ambientalista.

9 Retirado de Elster (1990, p. 68).

10 'Em um 'jogo' existem vários jogadores ou atores. Cada jogador deve adotar uma ação ou uma estratégia. Quando todos os jogadores tiverem escolhido suas estratégias, cada um obtém ganhos que dependem das estratégias escolhidas por ele e pelos outros. $O$ ganho de cada um depende da escolha de todos. [...] O ganho de cada um depende do ganho de todos. [...] A escolha de cada um depende da escolha de todos. O triunfo da teoria dos jogos é a sua capacidade de englobar simultaneamente as três séries de interdependências, citadas em itálico. Nada mais distante da verdade, portanto, do que alegar que a teoria dos jogos retrata o indivíduo como um átomo isolado egoísta." (Elster, 1989b, p. 183).

11 Para uma abordagem fiel à complexidade da teoria dos jogos, seria necessário discorrer sobre uma tipologia dos jogos, mas, nos limites deste trabalho, acreditamos que bastem as indicações precisas de Elster (1989, 1989b, 1994).

12 "Ótima", por sua vez, é uma posição qualquer, da qual nenhum ator racional deseja se afastar.

13 Esta é a situação descrita como "Jogo da Garantia ou "Jogo da Certeza" pela literatura sobre escolha racional.

14 A lógica, aqui, é a de que cada ator racional prefere que os demais contribuam sozinhos para obter o resultado pretendido por todos. Mas, ao mesmo tempo, todos desejam ou necessitam ter o resultado - e o terão, mesmo que não cooperem. Assim, há duas soluções possíveis: (i) cada um se dispõe a trabalhar pelo resultado pretendido, até mesmo sozinho; e/ou (ii) cada um se nega a trabalhar pelo resultado pretendido. A consequiência é que cada um deixará de cooperar se houver um número suficiente de outros cooperando. Ou, alternativamente, cada um cooperará se houver um número excessivo de outros que se negam a fazê-lo. Em situações deste tipo, cada ator racional coopera embora o outro não o faça, de modo que a não-cooperação de um força o outro a cooperar mais. Mas esta cooperação é muito frágil e incerta porque se o fato de um se recusar a cooperar obrigar, de fato, os outros a cooperarem mais, a 
tendência será de que todos corram para se negar a cooperar. Isso porque a vantagem fica com aquele que manifestar primeiro e mais firmemente a sua decisão de não cooperar, desde que os demais continuem cooperando. Situações deste tipo são descritas como "Jogo da Galinha" na literatura sobre escolha racional.

15 Para aprofundar o estudo dos mecanismos do equilíbrio e da negociação como formas de interação, ver Elster (1994). No caso, o peso maior de um dos negociadores sempre interfere nos rumos da negociação: "Pode ser uma vantagem se um dos negociadores for suficientemente forte para impor seu resultado preferido, não através de força, mas simplesmente dizendo aos outros para pegarem ou largarem. Por ser forte, importa-lhe menos que um acordo seja alcançado e, portanto, seu ultimato é mais verossímil do que seria colocado por um dos outros" (Elster, 1994, p. 171-172).

16 Tomamos emprestado um exemplo formulado, em outro contexto, pela professora Laura Maria Goulart Duarte, do CDS-UnB.

17 Elster (1994, p. 152) apresenta um exemplo próximo desse tipo de comportamento: "É melhor para todos os que vão diariamente à cidade se todos forem de ônibus do que se todos forem de carro, mas para cada um é sempre melhor ir de carro".

18 Custos significam renúncias, em sentido bastante amplo. São aqui definidos não só em termos financeiros, como os gastos com combustíveis, mas também, por exemplo, em termos de segurança, ou seja, de risco de roubo, assalto ou seqüestro relâmpago, e outros.

19 Note que mesmo não sendo um ecólogo, um professor universitário diante de uma entrevista, de um texto para publicação ou de um auditório, dificilmente negaria as vantagens do agir ecologicamente correto. No caso em questão, defenderia limitar ao máximo, ainda mais diante de boas oportunidades, o uso do transporte individual. Alusões ao sistema de transporte público de países, tais como, a França, a Suécia ou a Holanda, do tipo "quando eu estive lá..." com certeza, não faltariam.

20 Aqui uma norma poderia estar atuando e bloqueando uma ação orientada para o futuro, mas tudo leva a crer que esse não é o caso. É central na crítica ambientalista uma perspectiva orientada para um projeto futuro.

21 Nessa passagem Ulisses informa aos seus companheiros o conselho da Deusa Circe: "Não sòmente um nem dous, amigos, saibam/o que a deusa das deusas me predisse,/Para informados ou morrermos todos/Ou da Parca fugirmos. Das Sereias/evitar nos ordena o flóreo prado/ e a voz divina; a mim concede ouvi-las,/Mas ao longo do mastro em rijas cordas./E se pedir 
me desateis, vós outros/ De pés e mãos ligai-me com mais fôrça” (Homero, 1957, p. 170).

22 Se ficarmos com o exemplo de Ulisses e as Sereias, outra pergunta seria: até quando será possível viver preso ao mastro?

23 Segundo Saer (2002, p. 22): "Ulisses encarnaria, assim, a razão triunfante, a supremacia da ciência e da filosofia sobre o obscurantismo primitivo do mito e da lenda". Mas essa não é a única leitura possível. Esse mesmo comentador nos dá outras duas possibilidades: "Sabe-se que Ulisses conta a maioria de suas aventuras num reino aonde chegou depois de um miserável naufrágio: a ilha de Esquéria, [...] uma espécie de reino encantado [...].e só revela sua identidade quando ouve uma menção à história do cavalo de Tróia. Depois de passar algum tempo na ilha [...], os feácios o enviam de volta a Ítaca, sua terra natal, deitado numa embarcação carregada de enfeites e de víveres. Alguns helenistas vêem nesse episódio certa ruptura formal com a epopéia e sustentam que a travessia nessa embarcação fretada não passa de um rito fúnebre [...]. A solução é simples: as duas versões são corretas. [...] Como ocorre com qualquer outro objeto do mundo, por momentos acreditamos adivinhar o seu sentido, um sentido instável que, em seguida, nos foge outra vez. [...]. Se esse sentido roubado implica o triunfo ou a perdição será um persistente enigma e um persistente feitiço [...]". Nesse último caso, a conclusão que se apresenta é que nunca chegaremos definitivamente a um porto seguro. [...] Desencantar o mundo e vencer as crenças que lhe são contemporâneas, sempre será uma tarefa em aberto.

24 Ao comentar que a destruição do meio ambiente é, por vezes, quase impossível de desfazer, Elster (1994, p. 189) nos lembra de Marx: “como Marx comentou numa carta, a civilização com freqüência deixa um deserto atrás de si. Os nichos ecológicos desaparecem e, às vezes, os seus ocupantes também".

Abstract: The premise of this article is the understanding that there is, among the Brazilians, the existence of a horizontal and disseminated environmental conscience that does not consist with a daily practical concern on the subject. That is, even faced with the diagnosis of a global ecological crisis or the growth limits of our current socioeconomic standards, the individuals seem to act towards their selfdestruction. The question is: what makes well-informed individuals, who were taught how and why to act correctly, choose not to do it? How do you explain this phenomenon? In this small article, we propose an approximation between the environment issue, with its irregularity 
between theory and practice, and the theoretical-methodological instruments proposed by Elster.

Key-words: rationality, global ecological crisis, Elster.

Résumé: L'article part d'une constatation: chez les brésiliens, l'existence d'une conscience environnementale horizontale et disséminée n'est pas suivie d'une pratique quotidienne consistante. Autrement dit, nonobstant le diagnostique de la crise écologique globale ou des limites de la croissance de l'actuel modèle de développement socio-économique, les individus semblent agir vers l'autodestruction. Une question est donc posée: qu'est-ce qui amene les individus parfaitement renseignés sur comment et pourquoi agir correctement à n'est pas le faire? Comment expliquer ce phénomène? Ce bref article propose un rapprochement entre la problématique environnementale, le décalage entre ce qui se professe et ce qui se pratique, et l'instrumental théorique-méthodologique proposé par Jon Elster.

Mots-clés: rationalé, crise écologique global, Elster.

\section{Referências bibliográficas}

BARTHOLO Jr., Roberto. A crise do industrialismo: genealogia, riscos e oportunidades. In: BURSZTYN, Marcel; CHAIN, Arnaldo; LEITÃO, Pedro. Que crise é esta? Brasília: CNPq; São Paulo: Brasiliense, 1984.

BELLAMY, Richard. Liberalismo e sociedade moderna. São Paulo: UNESP, 1995.

BURSZTYN, Marcel. Armadilhas do progresso: contradições entre economia e ecologia. Sociedade e Estado, Brasília, v.10, n. 1, p. 97-125, 1995.

BURSZTYN, Marcel: CHAIN, Arnaldo; LEITÃO, Pedro. Que crise é esta? Brasília: CNPq; São Paulo: Brasiliense, 1984.

CRESPO, S. (Coord.). O que o brasileiro pensa sobre o meio ambiente, desenvolvimento e sustentabilidade. Rio de Janeiro: MMA/MAST/ ISER, 1997.

DaMATTA, Roberto. Em torno da representação de natureza no Brasil: pensamentos, fantasias e divagações. In: . Conta de mentiroso: sete ensaios de antropologia brasileira. Rio de Janeiro: Rocco, 1993. p. 91-124.

ELSTER, Jon. Peças e engrenagens das Ciências Sociais. Rio de Janeiro: Relume-Dumará, 1994. 
ELSTER, Jon. Racionalidade e normas sociais. Revista Brasileira de Ciências Sociais. São Paulo, v. 5, n. 12, p. 55-69, fev. 1990. . Ulises y las sirenas. México: Fondo de Cultura Económica, 1989. . Marxismo, funcionalismo e teoria dos jogos. Lua Nova. São Paulo, n. 17, p. 163-204, jun. 1989b.

FIGUEIREDO, Argelina. Apresentação. In: ELSTER, Jon. Peças $e$ engrenagens das Ciências Sociais. Rio de Janeiro: Relume-Dumará, 1994.

GOLDBLAT, David. Teoria social e ambiente. Lisboa: Instituto Piaget, 1998.

HERRERA, Amílcar. A crise da espécie. In: BURSZTYN, Marcel; CHAIN, Arnaldo; LEITÃO, Pedro. Que crise é esta? Brasília: CNPq; São Paulo: Brasiliense, 1984. (palestra proferida em 17.03.83).

HOMERO. A odisséia. São Paulo: Atena Editora, 1957.

LEFF, Enrique. Epistemologia ambiental. São Paulo: Cortez, 2001.

LEITE, Marcelo. Histórias naturais e morais. Folha de São Paulo, São Paulo, 17 fev. 2002. Caderno mais! p. 28, 2-3 col.

LINSKOG, Rolf. Introduction to this special issue on Sociology and the Environment. Acta Sociologica, Journal of the Scandinavian Sociological Association, v. 39, n. 1, 1996.

McCORMICK, John. Rumo ao Paraíso: a história do movimento ambientalista. Rio de Janeiro: Relume-Dumará, 1992.

REIS, Fábio W. Política e racionalidade: problemas de teoria e método de uma sociologia 'crítica' da Política. Belo Horizonte: UFMG/PROED/ RBEP, 1984.

RUA, Maria das Graças; BERNARDES, Franco Cesar. Escolha racional e novo institucionalismo: notas introdutórias. In: RUA, Maria das Graças; CARVALHO, Maria Izabel. O estudo da Política: tópicos selecionados. Brasília: Paralelo 15, 1998.

SAER, Juan José. Ulisses, o homem que o ouviu o canto. Folha de São Paulo. São Paulo, 10 fev. 2002. Caderno mais! p. 22, 1-4 col.

VÁZQUEZ, José C. [Sobrecapa]. In: ELSTER, Jon. Ulises y las sirenas. México: Fondo de Cultura Económica, 1989.

WEBER, Max. A Ética protestante e o espírito do Capitalismo. São Paulo: Pioneira, 1989.

WILSON, Edward. O Futuro da Vida. Folha de São Paulo. São Paulo, 17 fev. 2002. Caderno mais! p. 26-27-28, 1;1-3;1 col. 